\title{
Inflation persistence under semi-fixed exchange rate regimes: the European evidence 1974-1998
}

Citation for published version (APA):

Kool, C. J. M., \& Lammertsma, A. (2002). Inflation persistence under semi-fixed exchange rate regimes: the European evidence 1974-1998. METEOR, Maastricht University School of Business and Economics. METEOR Research Memorandum No. 015 https://doi.org/10.26481/umamet.2002015

Document status and date:

Published: 01/01/2002

DOI:

10.26481/umamet.2002015

Document Version:

Publisher's PDF, also known as Version of record

\section{Please check the document version of this publication:}

- A submitted manuscript is the version of the article upon submission and before peer-review. There can be important differences between the submitted version and the official published version of record.

People interested in the research are advised to contact the author for the final version of the publication, or visit the DOI to the publisher's website.

- The final author version and the galley proof are versions of the publication after peer review.

- The final published version features the final layout of the paper including the volume, issue and page numbers.

Link to publication

\footnotetext{
General rights rights.

- You may freely distribute the URL identifying the publication in the public portal. please follow below link for the End User Agreement:

www.umlib.nl/taverne-license

Take down policy

If you believe that this document breaches copyright please contact us at:

repository@maastrichtuniversity.nl

providing details and we will investigate your claim.
}

Copyright and moral rights for the publications made accessible in the public portal are retained by the authors and/or other copyright owners and it is a condition of accessing publications that users recognise and abide by the legal requirements associated with these

- Users may download and print one copy of any publication from the public portal for the purpose of private study or research.

- You may not further distribute the material or use it for any profit-making activity or commercial gain

If the publication is distributed under the terms of Article $25 \mathrm{fa}$ of the Dutch Copyright Act, indicated by the "Taverne" license above, 


\title{
INFLATION PERSISTENCE UNDER SEMI-FIXED EXCHANGE RATE REGIMES: THE EUROPEAN EVIDENCE 1974-1998
}

\author{
Clemens J.M. Kool and Alex Lammertsma*
}

March 2002

\begin{abstract}
:
In this paper, we empirically investigate the link between exchange rate accommodation and inflation persistence in Europe. We introduce the lagged level of the real exchange rate as an appropriate indicator of exchange rate accommodation. We correspondingly estimate a non-linear autoregressive inflation equation for ten European countries (excluding Germany) for the period 1974:1-1998:2. In the estimation procedure we allow for the presence of an unknown number of shifts in the mean of inflation. Our results provide supportive evidence for the existence of a positive link between exchange rate accommodation and inflation persistence for the smaller and more dependent ERM countries. No such link could be detected for the larger countries and the countries that remained outside the ERM for most of the period. Overall, our results provide modest support for the existence of the theoretically hypothesized link between exchange rate accommodation and inflation persistence.
\end{abstract}

* Kool is at the University Maastricht, while Lammertsma is at the Netherlands Bureau for Economic Policy Analysis (CPB), the Hague, the Netherlands. The authors gratefully acknowledge fruitful discussions and comments on previous drafts of the paper from Kees Koedijk, Joan Muysken, Tom van Veen, and participants of seminars at the University Maastricht, the Rijksuniversiteit Groningen (RUG), the Netherlands Bureau for Economic Policy Analysis, the University of Bonn (Germany), the Federal Reserve Bank of St. Louis, the International Atlantic Economic Conference, Montreal, 1999, and the Econometric Society European Meeting, 1999. The views expressed are those of the individual authors and do not necessarily reflect the official position of the CPB. Any remaining errors are our own. 


\section{Introduction}

Absent trend-like real exchange rate changes, inflation rates in countries participating in a joint fixed exchange rate system cannot permanently differ from one another according to relative purchasing power parity. The European experience over the past twenty years on this issue is a prime example. To achieve the goal of low and stable inflation, central banks in almost all WestEuropean countries have used exchange rate targeting relative to a low-inflation country (Germany) at some point in the eighties and nineties. As a result, inflation in almost all member countries of the ERM had converged to a low and stable level prior to the start of EMU in $1999 .{ }^{1}$

An important related but somewhat neglected issue is the speed of inflation convergence or equivalently the degree of inflation persistence. Clearly, high inflation persistence raises the disinflation costs for high-inflation countries and endangers the sustainability of a low-inflation monetary policy. Taylor (1980), Dornbusch (1982), Alogoskoufis and Smith (1991) - henceforth AS (1991) -, Alogoskoufis (1992), and Obstfeld (1995) develop variants of a similar theoretical model to show that inflation persistence is a function of the degree of monetary policy accommodation. ${ }^{2}$ AS (1991) and Alogoskoufis (1992) use a symmetrical two-country model and distinguish between average (world) inflation persistence and relative inflation persistence. Average persistence is determined by money supply accommodation, while relative persistence is a function of exchange rate accommodation. Dornbusch (1982) studies the link between exchange rate accommodation and domestic inflation persistence using a small open economy model.

In this paper, we concentrate on the relation between exchange rate accommodation and the degree of inflation persistence. Apart from its theoretical relevance, the issue is of considerable practical interest to countries that have to decide on the appropriate exchange rate system. In particular, a small open economy with relatively high inflation will not only or even primarily be interested in the fact that in due time a fixed exchange rate against a low-inflation currency will lead to inflation convergence. It may be more interested in questions like how long such convergence process will take and to what extent the length of the convergence period can

\footnotetext{
${ }^{1}$ Some countries on floating exchange rates experienced a similar inflation decline, see De Grauwe (1990). Monetary targeting or inflation targeting are appropriate alternative monetary policy strategies to reduce inflation.

${ }^{2}$ In Alogoskoufis (1992), price stickiness and persistence is based on staggered wage contracts, following Taylor (1979). AS (1991) base persistence on price adjustment costs, like Rotemberg (1982) and Mankiw (1985). Führer and Moore (1995) base an alternative model on relative wage considerations of private agents.
} 
be shortened by following a less accommodating policy. Of course, the issue - in terms of the choice of the degree of exchange rate accommodation - has lost most of its urgency for the previous EMS participants who now are part of EMU. ${ }^{3}$ However, a new wave of EU entrants will face a similar question. Countries like Poland, Hungary, the Czech Republic etc. are likely to enter EU with a rate of inflation still considerably exceeding inflation in the EMU area. These countries subsequently will be expected to join the new exchange rate mechanism ERM II in which the euro is the anchor country. The new entrants will be granted access to EMU only after they have obtained sufficient inflation convergence with the euro area.

Empirical evidence on changes in the degree of (relative) inflation persistence is scarce and mixed. Examples are AS (1991), Alogoskoufis (1992), Burdekin and Siklos (1999), Obstfeld (1995), Anderton (1997) and Bleaney (1999). Anderton (1997) is the only one focusing on the ERM experience in the seventies and eighties. Support for the null hypothesis that less exchange rate accommodation - that is, a more rigidly fixed exchange rate - implies lower inflation persistence weakens when the potential presence of level shifts in the mean of the inflation process is incorporated into the analysis, see for instance the evidence by Bleaney (1999), Anderton (1997), and Burdekin and Siklos (1999).

All studies share a common unsatisfactory feature in our view. In investigating changes in inflation persistence across time, they all hypothesize a one-to-one relation with changes in the prevailing formal exchange rate regime. In reality, exchange rate regimes appear far more complex than that, especially in recent times. A country like Italy, for example, continuously participated in the ERM from its start in 1979 to the ERM crisis in 1992. Obviously, the degree of actual monetary exchange rate accommodation varied considerably across this period. If indeed a positive relation exists between the degree of actual exchange rate accommodation and the degree of inflation persistence, neglecting time-variation in actual exchange rate accommodation within a fixed exchange rate regime, may yield incorrect conclusions.

In this paper, we primarily intend to extend this branch of the literature first by introducing a directly and continuously observable proxy for the degree of actual exchange rate accommodation. In particular, we propose to use the level of the (lagged) real exchange rate as an appropriate empirical proxy for the unobservable degree of cumulative past exchange rate

\footnotetext{
${ }^{3}$ To the extent that country-specific business cycles differ within EMU, national inflation differences may emerge. The degree of persistence of these differentials can't be attributed to nominal exchange rate accommodation anymore, but may have to do with other determinants of inflation.
} 
accommodation. Second, we test the relation between our proposed indicator of exchange rate accommodation and the degree of inflation persistence. We follow the literature and measure the latter as the first order autoregressive coefficient of the inflation process. For the test, we specify and estimate a non-linear autoregressive inflation equation for ten European countries for the period 1974:1-1998:2. We sequentially use a specification with the inflation level for each country as the dependent variable and one with the inflation differential of each country with Germany as the variable to be explained. The (non-linear) use of the real exchange rate in the inflation equation avoids the need to identify the degree of exchange rate accommodation by the formally prevailing exchange rate regime. Instead of arbitrarily choosing structural breakpoints between high and low accommodation periods, our approach allows for a continuous (and timevarying) estimate of both exchange rate accommodation and inflation persistence over the sample period. Third, we allow for the presence of multiple unknown shifts in the mean level of inflation using the approach of Bai and Perron (1998) and investigate the sensitivity of our results for such shifts. Overall, our results provide modest support for the existence of the theoretically hypothesized link between exchange rate accommodation and inflation persistence.

The paper is set up as follows. In section 2, we discuss ERM history and the use of the real exchange rate level as a proxy for accommodation. In section 3, we briefly summarize the accommodation literature, resulting in the specification of an inflation equation. In section 4 , we discuss the data, while the results are in section 5. Summary and conclusions are in section 6.

\section{Accommodation in the ERM}

The foundation of the European Monetary System (EMS) in 1979 with the corresponding fixed Exchange Rate Mechanism (ERM) is generally assumed to have contributed to the decline in inflation across Europe ${ }^{4}$. Some claim that the ERM functioned as a D-mark zone where Germany took the role of the low-inflation anchor country. High-inflation countries then borrowed credibility to lower domestic price expectations in an attempt to increase their own reputation at

\footnotetext{
${ }^{4}$ See Giavazzi and Pagano (1988), and Artis and Nachane (1990). In this literature, changing price expectations have a central position. Austria never formally participated in the ERM but committed to a unilateral peg against the D-mark. As such, it performed better in terms of exchange rate stability and inflation performance than all other ERM members with the exception of the Netherlands.
} 
relatively low costs ${ }^{5}$. An alternative - and potentially complementary - explanation is that a hard exchange rate peg of a high-inflation country to a low-inflation country results in a real exchange rate appreciation of the high-inflation country with subsequent crowding-out of exports and a decline of economic activity. A recession then will reduce inflationary pressures and invoke convergence to the low-inflation country.

The fact that most countries in Europe at some time opted either for a formally fixed exchange rate relative to Germany within the ERM or for an informal shadow fixed exchange rate regime outside of ERM, does not imply a large uniformity of exchange rate and inflation experiences across Europe. Within the ERM, exchange rates were adjustable through realignments rather than irrevocably fixed. A country like the Netherlands hardly ever used the escape of devaluation; others like Belgium, France and Italy resorted to it regularly, especially in the first years of the system. Realignments became scarcer only after 1986, implying stricter adherence to the fixed-exchange rate constraint. A new round of realignments - sometimes preceded by speculative attacks reminiscent of the early eighties - occurred during the ERM crises of 1992 and 1993. In addition, fluctuation bands were widened and the British pound and Italian lira (temporarily) exited from the ERM. After 1993, most of these currencies formally remained a fixed exchange rate system and actually maintained increasingly stable exchange rates with the Dmark (or the Ecu). However, it is unclear to what extent 15 percent fluctuation margins still pose a binding exchange rate constraint and how such a fixed exchange rate regime can be distinguished from a (managed) floating one. Spain (in 1989), the United Kingdom (in 1990), and Portugal (in 1992) joined the ERM at a later stage. Before joining, these countries sometimes tried to informally and unilaterally fix their exchange rate relative to the D-mark or the Ecu.

Overall, the above short description of exchange rate policies in Europe between 1979 and 1998 convincingly shows that it is infeasible to characterize the degree of a country's monetary (exchange rate) accommodation over the period 1974-1998 simply by looking at its formal exchange rate regime. Instead, we propose to look at one of the main characteristics of ERM performance. Over the whole period of analysis, Germany's reputation as the most arduous inflation-fighter has been unchallenged, because of its independent central bank, its anti-

\footnotetext{
${ }^{5}$ See Herz and Roger (1992), De Grauwe (1991), Fratianni and von Hagen (1990), and Koedijk and Kool (1992) for an analysis of the D-mark zone hypothesis. For recent evidence, see Hassapis, Pittis, and Prodromidis (1999) and Uctum (1999).
} 
inflationary monetary policies and its low inflation. For this reason, the D-mark informally served as the anchor of the fixed exchange rate regime of the ERM.

Consequently, any other country that chose to fix its currency to the D-mark either within or outside of the ERM, faced a gradual (bilateral) real appreciation of its on currency against the D-mark due to the positive inflation differential with Germany. As long as such country refused to accommodate the inflation differential with Germany, its real exchange rate appreciated. ${ }^{6}$ The refusal to devalue could and ultimately would lead to inflation convergence with Germany due to either a credibility effect on inflationary expectations, or a recession with consequent downward price pressures in goods or labor markets, or both. On the other hand, a devaluation to accommodate the accumulated inflation differential would cause a real depreciation and a (temporary) gain in competitiveness.

The (logarithmic) level of the real exchange rate provides a straightforward and continuous measure of the accumulated degree of past accommodation. This can also be seen by the equation that AS (1991) use to represent exchange rate accommodation:

$$
e_{t}=\varphi\left(p_{t}-p_{t}^{*}\right)
$$

Here, $\varphi$ is the accommodation parameter, $e$ is the logarithm of the nominal exchange rate of the home currency (expressed as the number of domestic currency units per unit of the benchmark currency), and $p$ and $p^{*}$ are the logarithms of the home and benchmark price level respectively. A low value of $\varphi$ close to zero implies that cumulated inflation differentials between the home country and Germany will almost completely feed into the real exchange rate. An overvalued home currency in real terms then indicates low accommodation. A high value of $\varphi$ (close to one) is a signal of full accommodation and will lead to a relatively stable real exchange rate. Excess accommodation - as would be the case with competitive devaluations - could even lead to an undervalued home currency. In this paper, we exploit the above characteristic of the real exchange rate within the context of the European (semi-) fixed exchange rate experience since 1973 and use it as the preferred indicator of the degree of exchange rate accommodation. ${ }^{7}$

\footnotetext{
${ }^{6}$ Throughout, we assume that trend real exchange rate changes due to real developments such as BalassaSamuelson effects are small compared to real exchange rate changes due to monetary policy.

${ }^{7}$ The debate on the validity of Purchasing Power Parity - and consequent stationarity of the real exchange rate - has not been decisively settled. Rogoff (1996) offers a balanced overview. Recent evidence in support of longrun PPP may be found in Lothian (1997), Lothian and Taylor (1997) and Koedijk, Schotman and van Dijk (1998).
} 


\section{Inflation persistence: theory and measurement}

For the discussion on the theoretical link between exchange rate accommodation and inflation persistence, we take AS (1991) as a starting point. They develop a symmetrical two-country model with forward-looking wage- and price setters. Monopolistically competitive firms set prices by minimizing an intertemporal loss function which penalizes price deviations from the optimal price on the one hand and price changes on the other, due for instance to menu costs. ${ }^{8}$ Their model results in the following AR(1) inflation process, where the $\operatorname{AR}(1)$ coefficient depends the on exchange rate accommodation parameter $\varphi$ from equation (1):

$$
\pi_{t}=c+\alpha(\phi) \pi_{t-1}+u_{t}
$$

where $\pi$ is inflation and $u$ represents the error term incorporating all unexpected shocks to inflation. $\alpha$ is the $\mathrm{AR}(1)$ parameter which measures the degree of persistence of the inflation process. The higher $\alpha$ and the closer to one, the more permanent any shock will affect future inflation. With $\alpha$ equal to one, a shock to inflation is fully permanent and inflation becomes a nonstationary process. We assume that the first derivative of $\alpha$ with respect to the accommodation parameter $\varphi$ is unambiguously positive. ${ }^{9}$

On the empirical level, different versions of equation (2) have been estimated. Most research has been done on inflation in (a subset of) OECD countries with sample periods generally starting in the late 1940 or early 1950 s and ending in the late eighties or early nineties. Examples are Alogoskoufis (1992), Obstfeld (1995), and Bleaney (1999). AS (1991) use data for a few countries - the U.S. and the U.K. - back to 1872. Anderton (1997) only starts his analysis in 1970. Overall, early results seemed to indicate that persistence was higher in floating exchange rate regimes associated with high monetary accommodation, than in fixed regimes associated with low accommodation.

More recently, Anderton (1997), Bleaney (1999), and Burdekin and Siklos (1999) show that estimates of inflation persistence are quite sensitive to the inclusion of shifts in mean inflation during constant exchange rate regimes. Support for the null hypothesis that less exchange rate accommodation - that is, a more rigidly fixed exchange rate - implies lower

\footnotetext{
${ }^{8}$ Alogoskoufis (1992) uses staggered wage contracts to end up with a similar model. We refer to Bleaney (1999) for an alternative but consistent exposition of the link between accommodation and persistence.

${ }^{9}$ We refer to AS (1991), Alogoskoufis (1992), Dornbusch (1982) and Kool and Lammertsma (1999, 2000) for a discussion on sufficient conditions for this first derivative to be positive.
} 
inflation persistence weakens when the potential presence of level shifts in the mean of the inflation process is incorporated into the analysis. Anderton (1997) and Bleaney (1999) both choose the timing of the structural break in the mean level of inflation exogenously. Subsequently, they test for a change in persistence before and after the structural break. Burdekin and Siklos (1999) let the data determine the timing of the structural break in the mean level of inflation endogenously, using the method of Perron and Vogelsang (1992). Afterwards, they apply the same approach as Anderton (1997) and Bleaney (1999). Bleaney (1999) correctly points out that the assumption of the independence of mean inflation shifts and the actual degree of accommodation (and of inflation persistence) may be incorrect.

In our view, at least two problems arise from the literature. First, the identification of periods within which persistence is constant using the prevailing exchange rate regime is generally inappropriate. Bleaney (1999) implicitly recognizes this. However, he explicitly links the variation in persistence within constant regime periods to independent changes in the main level of inflation, which is questionable as well. Anderton (1997) attempts to correct for the difference in accommodation between the early and later years of the ERM by introducing an arbitrary breakpoint in 1982 or 1983 . A second problem concerns the sensitivity of persistence estimates to shifts in the mean level of inflation by itself. So far, attempts to incorporate such level shifts all exogenously choose the breakpoints, Burdekin and Siklos (1999) excepted.

In contrast, we attempt to disentangle the effect of exchange rate accommodation from the effect of structural breaks in the mean level of inflation. First, we endogenously determine whether and how many structural breaks occur in the level of inflation, using the method of Bai and Perron (1998). Second, we estimate a nonlinear autoregressive inflation process using the lagged logarithmic level of the real exchange rate introduced in the previous section as a directly and continuously observable proxy for the cumulated degree of exchange rate accommodation at any point in time. It is defined as:

$$
q_{t}=e_{t}-\left(p_{t}-p_{t}^{*}\right)
$$

The most simple equation to test for changes in inflation persistence within exchange rate regimes then becomes the following modification of equation (2):

$$
\pi_{t}=c+\left(\alpha_{0}+\alpha_{1} q_{t-1}\right) \pi_{t-1}+u_{t}
$$

where persistence is measured by the expression $\left(\alpha_{0}+\alpha_{1} q_{t-1}\right)$. Since quarterly inflation series have more complicated dynamics than the AR(1) of equation (4), we include lags up till the fifth quarter. Also, in the empirical implementation, we apply a neutral (linear) transformation, 
rewriting the lagged inflation terms on the right hand side as first differences to facilitate inspection of the degree of persistence The final regression specification then becomes:

$$
\pi_{t}=c+\left(\alpha_{0}+\alpha_{1} q_{t-1}\right) \pi_{t-1}+\alpha_{2} \Delta \pi_{t-1}+\alpha_{3} \Delta \pi_{t-2}+\alpha_{4} \Delta \pi_{t-3}+\alpha_{5} \Delta_{\pi_{t-4}}+u_{t}
$$

with persistence being defined as $\left(\alpha_{0}+\alpha_{1} q_{t-1}\right) \cdot{ }^{10}$ Two versions of equation (5) will be estimated in section 5. In the first one, we focus on domestic inflation in each of the countries as dependent variable, while in the second variant the inflation differential with Germany is taken to be the dependent variable. The first version most closely matches the assumption of exogenous and stable inflation and inflation persistence in Germany. In the second one, we relax this assumption and take possible variation in Germany's inflation into account as well. In addition, equation (5) is augmented with dummy variables to endogenously determine possible structural breaks in the mean level of inflation, as suggested by Bai and Perron (1998).

\section{Data}

In the empirical analysis, we consider inflation persistence in ten European countries relative to Germany. These countries are Austria, Belgium, Denmark, France, Ireland, Italy, the Netherlands, Portugal, Spain, and the United Kingdom. Out of the current fifteen members of the European Union, Luxembourg has been excluded because of its monetary union with Belgium, Greece for data problems and Sweden and Finland for their only recent entry in the EU. Austria on the other hand is included because of its explicit unilateral D-mark peg over the past decades. Obviously, the above countries differ substantially both in size, openness, economic autonomy and actual exchange rate policy. On the one extreme, the Netherlands and Austria are small open economies neighboring Germany, which have maintained an almost perfect peg to the D-mark since the late seventies. On the other extreme, the United Kingdom is larger, less focused on continental Europe in terms of trade and more autonomous in policy matters. It has switched between episodes of almost pure floating and periods of D-mark shadowing. Consequently, the data allows for a comparison of widely differing degrees of exchange rate accommodation both between countries and over time per country.

\footnotetext{
${ }^{10}$ The nonlinear specification to capture continuous structural change is related to the Smooth Transition Autoregressive (STAR) models of Eitrheim and Teräsvirta (1996) and Lin and Teräsvirta (1994).
} 
For all countries plus Germany, quarterly CPI-series have been obtained from the IFSdatabase (line 64) through DATASTREAM for the period 1969-1998. For Ireland, the incomplete IFS-series has been updated using the series from the Irish Statistical Office. Subsequently, the CPI series have been used to compute quarter-to-quarter (logarithmic) inflation for each country ${ }^{11}$.

End-of-quarter exchange rates relative to the US dollar have been extracted from the same IFS-database (line ae). For the analysis, all US dollar exchange rates have been converted into Dmark exchange rates. The logarithm of each country's real exchange rate $(q)$ relative to Germany will play a central role in the analysis as it proxies for exchange rate accommodation. Empirically, it is defined as the logarithm of $\left[E^{*} P_{G} / P_{i}\right]$ where $\mathrm{E}$ is the amount of currency units $i$ per D-mark and $P_{G}$ and $P_{i}$ are the price index of Germany and country $i$ respectively.

In table 1, we first present some descriptive statistics on inflation. Panel A contains information on inflation levels per country, while panel B has the same information on each country's inflation differential with Germany. The sample period is 1974:1 to 1998:2. We decided to discard the data prior to 1974 to avoid the hectic inflationary experience in some countries in the run-up to the collapse of the Bretton Woods system. Preliminary computations show that in most countries the inflation process exhibits a structural break around this period. We are especially interested in the ERM period and the switch from (managed) floating in the seventies to increasingly fixed exchange rates in the 1980s and 1990s, and its consequences for the characteristics of the inflation process. In our view, the benefits of using a few extra years of data from the early seventies is outweighed by the corresponding need to add another structural break to the specification. The sample ends in 1998:2. On January $1^{\text {st }}, 1999$ most of the countries included entered EMU, thereby structurally changing the appropriate framework of analysis. With only one remaining monetary policy authority for the EMU area, a discussion on the degree of monetary accommodation implemented in an individual country loses its meaning and relevance. The exact appropriate endpoint for our sample of course is uncertain. One could argue data up till 1998:4 should be included as EMU started immediately thereafter. On the other hand, one could argue that already in late 1997 when it was known which countries would participate in the EMU, the loss of monetary autonomy for each individual country already was large enough to invalidate an analysis of monetary accommodation. However, our results appear robust to this

\footnotetext{
${ }^{11}$ Anderton (1997) computes inflation as the change in the log of the CPI relative to the same quarter in the previous year. This generates an overlapping data series with an MA(3) pattern and may affect estimated persistence.
} 
kind of minor changes in the length of the sample period. In the remainder of the paper, we thus concentrate on the period 1974:1-1998:2.

As might be expected, over the sample period both mean inflation and the standard deviation of inflation are lowest in Germany, the implicit anchor country of the ERM system. Austria, Belgium and the Netherlands form a group with only slightly higher inflation levels than Germany, in turn followed by Denmark and France. Portugal, Italy and Spain show he highest mean inflation, while Ireland and the UK take an intermediate position. In general, the standard deviation of inflation increases with the mean inflation level. Hardly any skew is observed, but most inflation series display fat tails (kurtosis), so that normality is rejected except for Germany and Austria. The inflation differentials in panel B show a corresponding picture.

Subsequently, we test for the stationarity of inflation levels and inflation differentials relative to Germany. In table 2 we summarize the evidence on the basis of our sample for the period 1974:1-1998:2. We apply both standard augmented Dickey Fuller (ADF) and PhillipsPerron (PP) unit root tests. The specification includes four lags, and alternatively only an intercept - indicated by $(\mathrm{C})$ - or an intercept and trend - indicated by $(\mathrm{T})$. The evidence is mixed. Phillips Perron tests in most cases reject a unit root both when only an intercept is included and when a trend is added. ADF tests on the other hand fail to reject a unit root in many cases. For inflation differentials more evidence in favor of stationarity is found than for inflation levels. Although the evidence appears ambiguous, we will proceed on the assumption that inflation levels and differentials are stationary series. ${ }^{12}$ In section 5.2 we will return to this issue in the context of the determination of structural breaks in mean inflation. It is well-known that the evidence in support of stationary inflation series considerably increases when structural break dummies are included, see Perron and Vogelsang (1992) for a discussion.

\section{Results}

In this section, we present and discuss our empirical evidence. In section 5.1, we estimate equation (5) for each country to analyze the significance of the link between the degree of exchange rate accommodation - as measured by the real exchange rate level - and the degree of inflation persistence. No account is taken yet of possible structural breaks in the mean level of

\footnotetext{
${ }^{12}$ Banerjee, Cockerell and Russell (2001) alternatively derive a model where the price level is I(2).
} 
inflation. In section 5.2, we specify a test for the endogenous determination of an unknown number of structural breaks in the mean level of inflation. Subsequently, we apply this test to the data and discuss the outcome, including its consequences for the stationarity of inflation. In section 5.3, we re-estimate equation (5) conditional on the inclusion of the endogenously determined break points in the inflation process and investigate the sensitivity of our results on persistence with respect to these structural breaks.

\subsection{Estimating inflation persistence}

In table 3 we present the regression results of country-wise estimation of equation (5). We only report the coefficients on the intercept, the lagged endogenous variable $\left(\alpha_{0}\right)$, and on the nonlinear real exchange rate term $\left(\alpha_{1}\right)$. The coefficients $\alpha_{0}$ and $\alpha_{1}$ together contain all available information on inflation persistence. No coefficients are reported for the other exogenous variables. This concerns the included lags of the change in inflation, which only help to more precisely determine the short-run dynamics of the inflation process. In case one or more of these lags are insignificant, they have been eliminated before a final estimation has been performed. White's heteroskedasticity-consistent standard errors have been used to compute t-values. The latter are reported in the table in parentheses below the coefficient estimates. For each country the fit and regression characteristics are acceptable.

The coefficient $\alpha_{1}$ which is assumed to capture the effect of exchange rate accommodation on inflation persistence is always positive and significantly so at the 5 percent level for Austria, Denmark, Italy, the Netherlands, Portugal, and the United Kingdom. For Belgium, France, Ireland and Spain the resulting coefficient is insignificant. Overall, we conclude that our results

provide modest support for the joint hypothesis of (i) exchange rate accommodation being appropriately measured by the level of the real exchange rate and (ii) inflation persistence being positively dependent on the level of accommodation.

In table 4, we report results for inflation differential regressions in a similar form as table 3. The evidence corroborates the level findings. Again a strictly positive effect of accommodation on inflation persistence is found, which is insignificant for France, Ireland, and Spain only.

\subsection{The determination of structural breaks in mean inflation}

Our approach to endogenously determine the number and timing of structural breaks in the mean level of inflation follows the sequential procedure outlined by Bai and Perron (1998). However, we start the discussion with Perron and Vogelsang (1992) - henceforth PV92 - who investigate 
the consequences of structural changes in the mean level of a time series variable on unit root tests. PV92 develop and propose an Innovational Outlier (IO) model. According to this univariate model, the dynamic reaction to a structural change in the mean affects the level of the series the same as any other shock. ${ }^{13}$ Under the null hypothesis of the absence of a unit root, the equation for an exogenous variable $y_{t}$ has the following finite autoregressive form:

$$
y_{t}=\mu+\alpha y_{t-1}+\delta D U_{t}+\sum_{i=1}^{k} \Delta y_{t-k}+e_{t}, \quad t=k+2, \ldots \ldots, T
$$

where $D U_{t}$ is a dummy variable that takes the value 1 if $t>T_{b}$ and 0 otherwise. $T_{b}$ is the unknown date at which the mean of the series shifts. ${ }^{14}$ Then, they use an estimation procedure in which $T_{b}$ subsequently takes each value from $k+2$ to $T$ for a given number of lagged terms $k$. They identify the optimal $T_{b}$ alternatively as the point where the absolute value of the t-test for $\alpha=1$ is maximized, or the point where the absolute value of the t-test for $\delta=0$ is maximized. For either case, they construct distribution tables for the respective t-statistics on the unit root test (for different choices of $k$ ) through Monte Carlo simulations. The similarity between our equation (5) and equation (6) as taken from PV92 is straightforward. The disadvantage of the PV92 framework is that only one structural break point is allowed, while in our application multiple break points might be present.

Bai and Perron (1998) extend the procedure to allow for a more general multivariate regression framework in which several coefficients can exhibit structural change at one point in time and in which multiple structural changes through time can occur. Their focus is not on unit roots, but on the consequences of the existence of structural breaks for estimation and testing procedures. Bai and Perron use an F-statistic to distinguish between the presence of $l$ and $l+1$ breaks. More in particular, for the model with $l$ breaks, the estimated break points, denoted by $\hat{T}_{1}, \ldots . ., \hat{T}_{l}$, are obtained through global minimization of the total sum of squared residuals. Then, each of the current $(l+1)$ segments is tested for the presence of an additional break. They then compare the overall minimal value of the sum of squared residuals (across all segments where an additional break is included) with the sum of squared residuals from the model with $l$ breaks,

\footnotetext{
${ }^{13}$ Alternatively, Perron and Vogelsang use an Additive Outlier (AO) model in which the change in mean is assumed to take effect instantaneously.

${ }^{14}$ Perron and Vogelsang include an additional term $\mathrm{D}(\mathrm{TB})_{\mathrm{t}}$ which takes the value 1 at time $T B$ and zero elsewhere to explicitly test the null hypothesis of a unit root. We have used this additional term too. However, it is generally insignificant in our regressions. Therefore, we don't report the results here.
} 
using an F-statistic. ${ }^{15}$ If the difference is sufficiently large, the null hypothesis of no change (a model with $l$ breaks) is rejected in favor of the alternative hypothesis (a model with $l+l$ breaks). The break date selected is the one associated with the global minimum of the total sum of squared residuals. More precisely, the test statistic is defined as:

$$
F_{T}(l+1 \mid l)=\left\{S_{T}\left(\hat{T}_{1}, \ldots, \hat{T}_{l}\right)-\operatorname{mininf}_{l \leq i \leq l+l} S_{T \in \Lambda_{i, n}}\left(\hat{T}_{1}, \ldots, \hat{T}_{i-1}, \tau, \hat{T}_{i}, \ldots, \hat{T}_{l}\right)\right\} / \hat{\sigma}^{2}
$$

where

$$
\Lambda_{i, \eta}=\left\{\tau ; \hat{T}_{i-1}+\left(\hat{T}_{i}-\hat{T}_{i-1}\right) \eta \leq \tau \leq \hat{T}_{i}-\left(\hat{T}_{i}-\hat{T}_{i-1}\right) \eta\right\}
$$

$S_{T}$ (.) denotes the sum of squared residuals and $\hat{\sigma}^{2}$ is a consistent estimate of $\sigma^{2}$ under the null hypothesis.

We follow the Bai and Perron procedure for a simple univariate framework in which only one variable - the intercept - is assumed to be subject to structural breaks. That is, we start with equation (6) in which the dependent variable $y$ either is the inflation level or the inflation differential with Germany for some country. We choose the number of lagged terms $k$ equal to 4 . To test for the occurrence of one break versus none, we first estimate equation (6) without the term $D U$. Subsequently we estimate the same equation including $D U$, with $T_{b}$ taking all values from $k+2$ to $T$. We compute the minimum value of the sum of squared residuals across all $T_{b}$ and compute the F-statistic from equation (7). Note that the Bai and Perron F-test in our univariate framework is equivalent to the PV92 t-test for the case of 0 versus 1 breaks. If it is insignificant, we conclude that structural breaks are absent. In the other case, at least one break is present, the timing of which is determined through minimization of the sum of squared residuals. We then continue by adding a second dummy $D U 1$ (representing a second structural break) and testing for its significance against the benchmark of one break and so on, until a next break is rejected. ${ }^{16}$

In table 5, we report the result of the procedure to endogenously determine the presence of structural shifts in the mean inflation level. ${ }^{17}$ For Austria, Belgium and the Netherlands no structural changes are found. All other countries have experienced one downward shift in the mean level of inflation. The timing of these shifts varies from 1978:1 for Spain to 1985:3 for Portugal. For Spain, the break approximately coincides with the start of monetary targeting after

\footnotetext{
${ }^{15}$ Bai and Perron use simulations to derive asymptotic critical values for the sequential F-test.

${ }^{16}$ We use the convention that the first and last few observations of the sample cannot be breakpoints. Moreover, we implement an additional restriction that at least five quarters must separate two adjacent break points. This way we avoid the identification of spurious break points in the data due to individual large outliers.

${ }^{17}$ The 5 percent critical level for 1 dummy is 9.63 , for two dummies 11.14 and for three dummies 12.16 .
} 
dismal inflation experience in the early 1970s. For the UK, we find a structural break in 1980:3 representing the well-known start of the contractionary monetary policy of the Thatcher regime. In that period, the British pound was floating and the downward shift in mean inflation is a case of less domestic monetary accommodation rather than less exchange rate accommodation. The other four countries in the sample are long-term members of the ERM. The estimated structural break points for Denmark, France, Italy and Ireland are close together. They vary from 1982:3 to 1984:2. This is by approximation the period that the exchange rate constraint in the ERM was effectively tightened. In March 1983, the final large realignment in a larger series was implemented. After that, realignments became less frequent. In his study on inflation persistence and the ERM, Anderton (1997) ad hoc chooses the breakpoint to be 1982:1 or 1983:2 for all countries. Our evidence suggests that the assumption that all countries did experience a structural shift at the same time is incorrect. Some - particularly the small economies closely aligned with Germany - had no break at all, while especially the countries that were not involved in the ERM in the early eighties had break points either years before or years after 1983. Only for the larger ERM countries, Anderton's assumption seems approximately right. In the last column of table 5, the t-statistic is given for the unit root test $\alpha=1$. According to PV92, the critical values at the 5 and 10 percent level equal 4.03 and 3.69 respectively for $T=100$ and $k=5$. In our case, $T=98$ and $k=4 .{ }^{18}$ For all countries that experience a significant structural shift in the mean level of inflation except Spain, a unit root now is rejected at the 5 percent level. For Austria, Belgium and the Netherlands no structural breaks were found.

In table 6 , the same information is given for the occurrence of structural breaks in each country's inflation differential with Germany. Now all countries have at least one break. Only Belgium has two. In general, the evidence is quite consistent with the level results, though. First, the estimated timing of the structural breaks with respect to inflation differentials is exactly the same as those for inflation levels for the UK and Spain. For Portugal, the timing is just one quarter off. Not surprisingly, these three countries are the ones least tightly connected to German monetary policy. Second, we find new structural breaks for inflation in the mid-seventies in Austria (1977:1), Belgium (1976:4), and the Netherlands (1977:1) relative to Germany. No such breaks were found for the levels in these countries. Graphical inspection shows that Germany started a disinflationary process around that time - it started monetary targeting in 1975 - which

\footnotetext{
${ }^{18}$ Table 4 in PV92 shows that minor variations in $T$ and $k$ hardly affect the critical values.
} 
was not immediately followed by the three countries mentioned leading to a gap with German inflation. Only in the late 1970s, inflation in Germany's three small neighbors slowly converges to the German level. Third, the observed shift in inflation levels in Denmark, France and Italy (but not Ireland) around 1982-1983 becomes statistically insignificant when we consider inflation differentials. Instead, we find shifts later on in the second half of the 1980s. These occur in 1986:1 in Italy, 1987:2 in France, and 1989:1 in Denmark. For Belgium, a similar shift is found in 1987:4. We explain this phenomenon by pointing to the fact that German inflation declined in the early 1980 s as well as for the other countries. Consequently, the downward shift seen in the levels is less pronounced in the differentials and therefore fails to gain significance. Note though that in many cases, the second structural breakpoint for these countries - which is statistically insignificant - is in the early eighties and closely corresponds to the significant first break point in the level analysis. It suggests that the above four countries fail to achieve full convergence with Germany in the early eighties. The break points found for the differentials represent significant (relative) convergence gains compared to German inflation later on in time. The last column shows that a unit root for inflation differentials can be formally rejected at the 5 percent level for all countries except Spain. In the next section, we will use the information on the structural breaks found here in our extended investigation of inflation persistence.

\subsection{Inflation persistence conditional on changes in mean inflation}

In table 7 we again present the regression results of country-wise estimation of equation (5) now conditional on the inclusion of the endogenously determined break points in the mean inflation level. The format is similar to table 3 . Of course the dummy variables and the timing of the break points (see table 5) differ per country. For Austria, Belgium and the Netherlands no dummy has been included as we found no significant structural break All coefficients on the dummy variables are significantly negative, reflecting the sizable downward shift in inflation in these seven countries at some point in the 1980s. For four countries, we report a significant accommodation parameter $\left(\alpha_{1}\right)$ in table 7 , to wit Austria, Denmark, Portugal, and the Netherlands. In table 8 , we report the results for inflation differential regressions including structural break dummies. The evidence is slightly weaker than for the levels regressions in table 7. The parameter $\alpha_{1}$ on the real exchange rate term is (marginally) significant for Belgium, Denmark, Italy and Portugal. 
Although the results are mixed, it is exactly the group of small and open economies for which we find this positive evidence, as would be theoretically expected. For the larger countries like France, the UK, Italy and Spain the exchange rate accommodation model may be less appropriate than the domestic monetary accommodation model. These countries may have enjoyed a higher degree of domestic monetary autonomy due to their size. This holds especially true for the UK as it in fact formally floated against the D-mark in the late seventies and early eighties and initiated a disinflation on its own in this period through tight domestic monetary policy. ${ }^{19}$. But even France and Italy may have been able to partly determine their own monetary policy in the ERM for a long time. This interpretation is consistent with some of the D-mark zone literature, see Herz and Roger (1992). Belgium and Ireland are the only two small ERM countries for which no significant accommodation effect is observed. For Ireland, this may be explained by the fact that Ireland was closely connected with the UK through a one-to-one currency peg up till 1979 and through extensive bilateral trade for the whole period.

In short, we find that our set of ten countries can be divided in two. The majority of the group of small open dependent economies displays a significant exchange rate accommodation effect on persistence. Belgium and Ireland are the exceptions. The group of larger economies with traditionally a more independent monetary policy does not. We interpret the evidence as modest support for our null hypothesis.

In our view, there is a second argument to interpret the evidence as modest support of our null hypothesis. As stated before, a strong commitment to a fixed exchange rate may simultaneously lead to a lower mean inflation level and an appreciated real exchange rate. Bleaney (1999) also suggests that the shift of the mean inflation level may not be exogenous and may not be unrelated to the degree of exchange rate accommodation. In that case, disentangling the effect of lower accommodation on the inflation level and the inflation persistence respectively becomes quite hard. That we do find an independent effect of exchange rate accommodation on inflation persistence after accounting for the level effect strengthens our case.

19 Bean (1988) argues that the implemented monetary contraction explains approximately half of the observed real appreciation of the pound against other currencies in this period. In his view, the other half of the appreciation of the pound in the early 1980s comes from the discovery and exploitation of natural resources in British part of the North Sea. 


\section{Summary and conclusions}

In most industrialized countries, inflation was high and rising in the seventies, declined in the eighties and stabilized at relatively low levels in the nineties. Since the early 1980 s monetary policy became increasingly oriented at price stability. In Europe, the founding of the European Monetary System in 1979 and the functioning of the ERM since that time has contributed to the convergence of inflation in the participating countries to that of Germany, the low-inflation anchor country.

Strikingly, little attention has been paid empirically to the development of inflation persistence in relation to the choice of exchange rate regime. The issue deserves closer attention in our view, however, especially in view of the policy choices many of the current EU candidates will have to make in the future about their monetary policy regime.

In this paper, we have extended the literature first by introducing a directly and continuously observable proxy for the degree of actual exchange rate accommodation, to wit the level of the (lagged) real exchange rate. The (non-linear) use of the real exchange rate in the inflation equation avoids the need to identify the degree of exchange rate accommodation by the formally prevailing exchange rate regime. Our innovative approach allows for a continuous (and time-varying) estimate of both exchange rate accommodation and inflation persistence over the sample period. Also, we allow for the presence of multiple unknown shifts in the mean level of inflation using the approach of Bai and Perron (1998) and investigate the sensitivity of our results for such shifts. Our breakpoint analysis suggests that the assumption - see for instance Anderton (1997) - that all countries did experience a structural shift in the mean level of inflation at the same time is incorrect.

Using the non-linear autoregressive framework for inflation, we have estimated and tested the relation between exchange rate accommodation and the degree of inflation persistence using a non-linear autoregressive inflation equation for ten European countries for the period 1974:11998:2. We do this both for the inflation level of each country for its inflation differential with Germany.

Our results provide supportive evidence for the existence of a positive link between exchange rate accommodation and inflation persistence for the smaller and more dependent ERM countries, even when mean level shifts in inflation are appropriately accounted for. No such link could be detected for the larger countries and the countries that remained outside the ERM for 
most of the period. Overall, our results provide modest support for the existence of the theoretically hypothesized link between exchange rate accommodation and inflation persistence. It supports the view that the assumption of a one-to-one relation between changes in the prevailing formal exchange rate regime and changes in inflation persistence is inappropriate.

For new entrants into the EU and the ERM-II, it may be comforting to know that a strong commitment to maintaining the fixed exchange rate with the euro not only may have the benefit of a lower mean inflation level in due time. There is evidence now that it also can speed up convergence making the transition period of disinflation shorter. Also, we have demonstrated that it is not the formal fixing in itself that has the positive effects but the actually implemented policy. A caveat applies though. The real economic cost of the real exchange rate appreciation for the domestic economy is not zero. Especially when trend like real exchange rate appreciations still persist due to for example Balassa-Samuelson effects, the costs of fixing may be larger than the combined benefit of reduced inflation levels and persistence. At some point the trade-off may change. Then it is good to remember that a strong commitment to a fixed exchange rate may pay off in more than one way. 


\section{References}

Alogoskoufis, G.S., "Monetary Accommodation, Exchange Rate Regimes and Inflation Persistence", The Economic Journal, May 1992, 102, 461-480.

Alogoskoufis, G.S. and R. Smith, "The Phillips Curve, the Persistence of Inflation, and the Lucas Critique: Evidence from Exchange-rate Regimes", The American Economic Review, December 1991, 81, 1254-1275.

Anderton, R., "Did the Underlying Behaviour of Inflation Change in the 1980s? A Study of 17 Countries", Weltwirtschaftliches Archiv, 1997, 133, 22-38.

Artis, M., and D. Nachane, "Wages and Prices in Europe: A Test of the German Leadership Hypothesis", Weltwirtschaftliches Archiv, 1990, 126, 59-77.

Banerjee, A., L. Cockerell, and B. Russell, “An I(2) Analysis of Inflation and the Markup”, Journal of Applied Econometrics, 2001, 16, 221-240.

Bai, J., and P. Perron, "Estimating and Testing Linear Models with Multipl Structural Changes", Econometrica, January 1998, 66, 47-78.

Bean, C.R., "Sterling Misalignment and British Trade Performance (with comments)", in R.C. Marston (ed.), Misalignment of Exchange Rates: Effects on Trade and Industry, 1988, 3976.

Bleaney, M., "Price and Monetary Dynamics Under Alternative Exchange Rate Regimes", IMF Working Paper WP/99/67, 1999, International Monetary Fund, Washington D.C.

Burdekin, R.C.K., and P.L. Siklos, "Exchange Rate Regimes and Shifts in Inflation Persistence: Does Nothing Else Matters?", Journal of Money, Credit and Banking, May 1999, 31, 235 247.

De Grauwe, P., "The Cost of Disinflation and the European Monetary System”, Open Economies Review, 1990, 1, 147-173.

De Grauwe, P., "Is the EMS a DM-Zone?", in A. Steinherr and D. Weiserbs (eds.): Evolution of the International and Regional Monetary Systems, London: Macmillan, 1991.

Dornbusch, R., "PPP Exchange-Rate Rules and Macroeconomic Stability”, Journal of Political Economy, February 1982, 90, 158-165.

Eitrheim, $\varnothing$, and T. Teräsvirta, "Testing the Adequacy of Smooth Transition Autoregressive Models", Journal of Econometrics, 1996, 74, 59-75. 
Fratianni, M., and J. von Hagen, "German Dominance in the EMS: The Empirical Evidence”, Open Economies Review, 1990, 1, 86-107.

Fuhrer, J., and G. Moore, “Inflation persistence”, The Quarterly Journal of Economics, February $1995,110,127-159$.

Giavazzi, F., and M. Pagano, “The Advantage of Tying One's Hands: EMS Discipline and Central Bank Credibility”, European Economic Review, 1988, 32, 1055-1082.

Hassapis, C., N. Pittis, and K. Prodromidis, "Units Roots and Granger Causality in the EMS Interest Rates: The German Dominance Hypothesis Revisited”, Journal of International Money and Finance, 1999, 18, 47-73.

Herz, B., and W. Roger, "The EMS is a Greater Deutsch-Mark Area", European Economic Review, October 1992, 36, 1413-1425.

Koedijk, C.G., and C.J.M. Kool, "Dominant Interest and Inflation Differentials within the EMS", European Economic Review, May 1992, 36, 925-943.

Koedijk, C.G., P. Schotman, and M.A. van Dijk, "The Re-emergence of PPP in the 1990s", Journal of International Money and Finance, February 1998, 17, 51-61.

Kool, C.J.M., and A. Lammertsma, "Exchange Rate Accommodation and Inflation Persistence in Europe: 1970-1998", METEOR Research Memorandum 99/005, 1999, University Maastricht.

Kool, C.J.M., and A. Lammertsma, "The Phillips Curve, the Persistence of Inflation and the Lucas Critique: Evidence from Exchange-Rate Regimes: Comment”, The American Economic Review, 2000, 90, 312-315.

Lin, C., and T. Teräsvirta, "Testing the Constancy of Regressions Parameters against Continuous Structural Change", Journal of Econometrics, 1994, 62, 211-228.

Lothian, J.B., "Multi-Country Evidence on the Behavior of Purchasing Power Parity under the Current Float", Journal of International Money and Finance, February 1997, 16, 19-35.

Lothian, J.B, and M.P. Taylor, "Real Exchange Rate Behavior”, Journal of International Money and Finance, December 1997, 16, 745-754.

Mankiw, N.G., "Small Menu Costs and Large Business Cycles: A Macroeconomic Model of Monopoly", The Quarterly Journal of Economics, May 1985, 100, 529-539.

Obstfeld, M., "International Currency Experience: New Lessons and Lessons Relearned", Brookings Papers on Economic Activity, 1995, 1, 119-220. 
Perron, P., "Testing for a Unit Root in a Time Series with a Changing Mean", Journal of Business and Economics Statistics, 1990, 8, 153-162.

Perron, P., and T.J. Vogelsang, "Nonstationarity and Level Shifts With an Application to Purchasing Power Parity”, Journal of Business and Economics Statistics, July 1992, 10, 301-320.

Rogoff, K., “The Purchasing Power Parity Puzzle”, Journal of Economic Literature, 1996, 34, 647-668.

Rotemberg, J.J., "Sticky Prices in the United States”, Journal of Political Economy, 1982, 90, 1187-1211.

Taylor, J.B., "Staggered Wage Setting in a Macro Model”, American Economic Review, 1979, 69, 108-113.

Taylor, J.B., “Aggregate Dynamics and Staggered Contracts”, Journal of Political Economy, $1980,88,1-23$.

Uctum, M., "European Integration and Asymmetry in the EMS”, Journal of International Money and Finance, 1999, 18, 769-798. 
Table 1 Descriptive Statistics 1974:1-1998:2

\begin{tabular}{|c|c|c|c|c|c|c|c|c|c|c|c|}
\hline & Austria & Belgium & Denmark & France & Germany & Ireland & Italy & Netherlands & Portugal & Spain & UK \\
\hline & \multicolumn{11}{|c|}{ Panel A: Inflation Levels } \\
\hline Mean & 3.86 & 4.64 & 5.77 & 5.98 & 3.11 & 7.70 & 9.46 & 3.64 & 13.73 & 9.43 & 7.70 \\
\hline Median & 3.98 & 3.87 & 4.48 & 3.93 & 2.91 & 5.04 & 7.38 & 3.13 & 11.72 & 8.20 & 6.27 \\
\hline Maximum & 12.71 & 16.94 & 20.47 & 16.84 & 9.59 & 30.87 & 25.74 & 12.49 & 46.69 & 31.18 & 35.89 \\
\hline Minimum & -3.40 & -1.43 & -2.30 & -1.05 & -2.14 & -3.17 & 0.59 & -5.83 & 0.54 & 0.30 & -2.90 \\
\hline Std.Dev. & 3.37 & 3.69 & 4.86 & 4.43 & 2.38 & 7.57 & 6.34 & 3.21 & 9.68 & 6.33 & 6.78 \\
\hline Skewness & 0.25 & 0.97 & 0.96 & 0.54 & 0.33 & 1.24 & 0.87 & 0.38 & 0.83 & 0.96 & 1.40 \\
\hline Kurtosis & 3.12 & 3.95 & 3.43 & 2.06 & 2.84 & 3.72 & 2.82 & 3.86 & 3.20 & 3.76 & 5.28 \\
\hline $\begin{array}{l}\text { Jarque- } \\
\text { Bera }\end{array}$ & 1.06 & 19.12 & 15.92 & 8.36 & 1.85 & 27.03 & 12.46 & 5.35 & 11.31 & 17.32 & 53.42 \\
\hline \multirow[t]{2}{*}{ Probability } & 0.59 & 0.00 & 0.00 & 0.02 & 0.40 & 0.00 & 0.00 & 0.07 & 0.00 & 0.00 & 0.00 \\
\hline & \multicolumn{11}{|c|}{ Panel B: Inflation Differentials (versus Germany) } \\
\hline Mean & 0.74 & 1.53 & 2.66 & 2.86 & & 4.59 & 6.35 & 0.52 & 10.62 & 6.31 & 4.59 \\
\hline Median & 0.46 & 1.36 & 2.35 & 2.20 & & 2.94 & 5.38 & 0.49 & 9.40 & 4.9 & 3.83 \\
\hline Maximum & 9.18 & 12.91 & 19.31 & 10.26 & & 23.72 & 21.30 & 6.82 & 42.00 & 30.02 & 28.24 \\
\hline Minimum & -5.16 & -3.86 & -6.92 & -3.92 & & -6.31 & -2.44 & -7.98 & -2.50 & -2.20 & -9.82 \\
\hline Std.Dev. & 2.58 & 3.04 & 4.55 & 3.69 & & 6.31 & 5.33 & 2.79 & 8.84 & 5.81 & 5.8 \\
\hline Skewness & 0.16 & 0.76 & 0.90 & 0.23 & & 1.03 & 0.87 & -0.33 & 0.89 & 1.17 & 1.06 \\
\hline Kurtosis & 3.38 & 4.18 & 4.49 & 1.98 & & 3.67 & 3.38 & 3.94 & 3.44 & 4.94 & 5.21 \\
\hline $\begin{array}{l}\text { Jarque- } \\
\text { Bera }\end{array}$ & 1.00 & 15.19 & 22.23 & 5.07 & & 19.24 & 12.91 & 5.37 & 13.65 & 37.89 & 38.33 \\
\hline Probability & 0.61 & 0.00 & 0.00 & 0.08 & & 0.00 & 0.00 & 0.07 & 0.00 & 0.00 & 0.00 \\
\hline
\end{tabular}


Table $2 \quad$ Unit Root Tests 1974:1-1998:2

\begin{tabular}{|c|c|c|c|c|c|c|c|c|}
\hline \multirow[b]{2}{*}{ Countries } & \multicolumn{4}{|c|}{ Inflation levels } & \multicolumn{4}{|c|}{ Inflation differentials } \\
\hline & $\mathrm{PP}(\mathrm{C})$ & $\mathrm{ADF}(\mathrm{C})$ & $\mathrm{PP}(\mathrm{T})$ & $\operatorname{ADF}(\mathrm{T})$ & $\mathrm{PP}(\mathrm{C})$ & $\operatorname{ADF}(\mathrm{C})$ & $\mathrm{PP}(\mathrm{T})$ & $\operatorname{ADF}(\mathrm{T})$ \\
\hline Austria & -8.99 & -1.71 & -11.80 & -2.52 & -12.49 & -3.34 & -13.64 & -4.40 \\
\hline Belgium & -3.70 & -1.91 & -5.80 & -3.42 & -5.60 & -2.63 & -7.33 & -4.49 \\
\hline Denmark & -5.92 & -1.99 & -9.86 & -4.31 & -7.81 & -2.20 & -10.49 & -3.99 \\
\hline France & -2.45 & -1.19 & -4.89 & -3.04 & -4.43 & -1.49 & -7.86 & -4.40 \\
\hline Germany & -5.64 & -2.27 & -6.27 & -2.37 & & & & \\
\hline Ireland & -4.63 & -1.25 & -7.43 & -2.67 & -5.22 & -1.53 & -8.46 & -3.62 \\
\hline Italy & -3.00 & -1.57 & -6.13 & -4.62 & -3.96 & -1.94 & -7.64 & -5.89 \\
\hline Netherlands & -5.16 & -1.57 & -6.83 & -1.86 & -9.34 & -2.07 & -10.58 & -2.67 \\
\hline Portugal & -5.41 & -1.49 & -8.67 & -4.01 & -5.72 & -1.79 & -8.54 & -3.92 \\
\hline Spain & -4.36 & -0.64 & -9.33 & -2.92 & -5.14 & -1.01 & -8.64 & -3.00 \\
\hline U Kingdom & -5.17 & -2.14 & -7.45 & -3.81 & -6.08 & -2.56 & -8.33 & -4.35 \\
\hline
\end{tabular}

Note: $\quad$ Critical values are $-3.50(1 \%),-2.89(5 \%)$ and $-2.58(10 \%)$ respectively for $\mathrm{PP}(\mathrm{C})$ and $\mathrm{ADF}(\mathrm{C})$ tests. They are $-4.05(1 \%),-3.46(5 \%)$ and $-3.16(10 \%)$ for the $\mathrm{PP}(\mathrm{T})$ and $\operatorname{ADF}(\mathrm{T})$ tests. 
Table 3 Inflation level regressions without breaks, 1974:1- 1998:2

\begin{tabular}{|l|c|c|c|c|c|c|c|c|c|c|}
\hline & Austria & Belgium & Denmark & France & Ireland & Italy & $\begin{array}{c}\text { Nether } \\
\text { lands }\end{array}$ & Portugal & Spain & UK \\
\hline Intercept & 1.54 & 0.70 & 1.85 & 0.25 & 0.98 & 1.51 & 0.23 & 3.20 & 0.48 & 1.98 \\
& $(3.25)$ & $(2.66)$ & $(2.94)$ & $(1.22)$ & $(1.85)$ & $(2.34)$ & $(0.80)$ & $(2.37)$ & $(0.66)$ & $(2.91)$ \\
\hline$\alpha_{0}$ & 0.56 & 0.85 & 0.63 & 0.93 & 0.81 & 0.79 & 0.93 & 0.71 & 0.91 & 0.70 \\
& $(5.42)$ & $(14.08)$ & $(5.34)$ & $(20.12)$ & $(8.05)$ & $(11.36)$ & $(16.92)$ & $(7.09)$ & $(10.41)$ & $(6.76)$ \\
\hline$\alpha_{1}$ & 2.54 & 1.45 & 3.98 & 0.49 & 0.91 & 0.68 & 3.07 & 1.45 & 0.19 & 0.93 \\
& $(5.52)$ & $(1.18)$ & $(4.49)$ & $(0.93)$ & $(1.50)$ & $(1.99)$ & $(3.39)$ & $(2.69)$ & $(0.42)$ & $(3.26)$ \\
\hline adj. R`2 & 0.62 & 0.68 & 0.48 & 0.80 & 0.58 & 0.69 & 0.70 & 0.44 & 0.64 & 0.60 \\
\hline S.E.E. & 2.07 & 2.08 & 3.49 & 1.97 & 4.88 & 3.54 & 1.76 & 7.25 & 3.80 & 4.29 \\
\hline
\end{tabular}

Table 4 Inflation differential regressions without breaks, 1974:1- 1998:2

\begin{tabular}{|l|c|c|c|c|c|c|c|c|c|c|}
\hline & Austria & Belgium & Denmark & France & Ireland & Italy & $\begin{array}{c}\text { Nether } \\
\text { lands }\end{array}$ & Portugal & Spain & UK \\
\hline Intercept & 0.41 & 0.38 & 0.62 & 0.26 & 0.75 & 1.76 & 0.21 & 2.97 & 0.78 & 1.80 \\
& $(2.01)$ & $(1.55)$ & $(1.16)$ & $(0.99)$ & $(1.72)$ & $(2.81)$ & $(1.09)$ & $(2.42)$ & $(1.19)$ & $(3.60)$ \\
\hline$\alpha_{0}$ & 0.35 & 0.78 & 0.67 & 0.89 & 0.78 & 0.67 & 0.82 & 0.66 & 0.84 & 0.53 \\
& $(2.89)$ & $(10.27)$ & $(5.08)$ & $(13.04)$ & $(7.53)$ & $(7.77)$ & $(5.78)$ & $(6.33)$ & $(6.96)$ & $(6.52)$ \\
\hline$\alpha_{1}$ & 4.36 & 5.41 & 5.23 & 1.31 & 0.90 & 0.91 & 6.63 & 1.52 & 0.37 & 1.47 \\
& $(3.37)$ & $(2.38)$ & $(3.32)$ & $(1.09)$ & $(1.24)$ & $(1.95)$ & $(2.51)$ & $(2.26)$ & $(0.60)$ & $(5.20)$ \\
\hline adj. R $^{\wedge} 2$ & 0.38 & 0.50 & 0.32 & 0.58 & 0.46 & 0.54 & 0.47 & 0.38 & 0.50 & 0.56 \\
\hline S.E.E. & 2.04 & 2.14 & 3.74 & 2.39 & 4.64 & 3.63 & 2.04 & 6.97 & 4.11 & 3.87 \\
\hline
\end{tabular}


Table 5 Structural Breaks Inflation Levels

\begin{tabular}{|c|c|c|c|c|c|c|}
\hline Country & \# Dummies & SSE & S.E. & $\mathbf{F}$ & Break point & $\mathbf{t}_{\alpha}$ \\
\hline \multirow[t]{2}{*}{ Austria } & 0 dummy & 447,48 & 2,21 & & & \\
\hline & 1 dummy & 420,16 & 2,15 & 5,62 & 1984:2 & - \\
\hline \multirow[t]{2}{*}{ Belgium } & & 416,44 & 2,13 & & & \\
\hline & 1 dummy & 375,90 & 2,03 & 8,96 & 1985:3 & - \\
\hline \multirow[t]{3}{*}{ Denmark } & & 1251,82 & 3,69 & & & \\
\hline & 1 dummy & 1040,18 & 3,38 & 15,55 & 1983:1 & 4,81 \\
\hline & 2 dummies & 921,82 & 3,20 & 10,36 & 1990:1 & \\
\hline \multirow[t]{3}{*}{\begin{tabular}{|l|} 
France \\
\end{tabular}} & & 360,24 & 1,98 & & & \\
\hline & 1 dummy & 306,40 & 1,83 & 13,75 & 1983:3 & 4,13 \\
\hline & 2 dummies & 274,17 & 1,75 & 9,57 & 1985:3 & \\
\hline \multirow[t]{3}{*}{ Ireland } & & 2299,18 & 5,00 & & & \\
\hline & 1 dummy & 1897,74 & 4,57 & 16,06 & 1982:3 & 4,36 \\
\hline & 2 dummies & 1791,04 & 4,46 & 5,12 & 1979:1 & \\
\hline \multirow[t]{3}{*}{ Italy } & 0 dummy & 1193,21 & 3,60 & & & \\
\hline & 1 dummy & 948,38 & 3,23 & 18,88 & 1984:2 & 5,13 \\
\hline & 2 dummies & 875,81 & 3,12 & 6,96 & 1986:1 & \\
\hline \multirow[t]{2}{*}{ Netherlands } & 0 dummy & 304,88 & 1,82 & & & \\
\hline & 1 dummy & 276,61 & 1,74 & 8,53 & 1976:3 & - \\
\hline \multirow[t]{3}{*}{ Portugal } & 0 dummy & 5261,01 & 7,56 & & & \\
\hline & 1 dummy & 4486,68 & 7,02 & 13,54 & 1985:3 & 4,20 \\
\hline & 2 dummies & 3971,80 & 6,64 & 10,44 & 1992:3 & \\
\hline \multirow[t]{3}{*}{ Spain } & 0 dummy & 1309,45 & 3,77 & & & \\
\hline & 1 dummy & 1079,25 & 3,44 & 16,17 & 1978:1 & 2,95 \\
\hline & 2 dummies & 971,58 & 3,29 & 9,10 & 1979:2 & \\
\hline \multirow[t]{3}{*}{ UK } & 0 dummy & 1852,13 & 4,49 & & & \\
\hline & 1 dummy & 1532,50 & 4,10 & 15,88 & 1980:3 & 4,77 \\
\hline & 2 dummies & 1472,50 & 4,04 & 3,57 & 1979:2 & \\
\hline
\end{tabular}


Table 6 Structural Breaks Inflation Differentials

\begin{tabular}{|c|c|c|c|c|c|c|}
\hline Country & \# Dummies & SSE & S.E. & $\mathbf{F}$ & Break point & $\mathbf{t}_{\alpha}$ \\
\hline \multirow[t]{3}{*}{ Austria } & 0 dummy & 419,32 & 2,13 & & & \\
\hline & 1 dummy & 371,66 & 2,02 & 10,46 & 1977:1 & 4,75 \\
\hline & 2 dummies & 340,96 & 1,95 & 7,52 & 1988:4 & \\
\hline \multirow[t]{4}{*}{ Belgium } & & 468,85 & 2,26 & & & 4,50 \\
\hline & 1 dummy & 401,66 & 2,10 & 13,19 & 1976:4 & 6,30 \\
\hline & 2 dummies & 340,61 & 1,95 & 13,83 & 1987:4 & \\
\hline & 3 dummies & 318,00 & 1,89 & 5,97 & 1982:1 & \\
\hline \multirow[t]{3}{*}{ Denmark } & & 1384,04 & 3,88 & & & \\
\hline & 1 dummy & 1223,27 & 3,67 & 10,69 & 1989:1 & 4,17 \\
\hline & 2 dummies & 1133,00 & 3,55 & 6,71 & 1983:1 & \\
\hline \multirow[t]{3}{*}{ France } & & 526,85 & 2,39 & & & \\
\hline & 1 dummy & 431,89 & 2,18 & 16,58 & 1987:2 & 4,71 \\
\hline & 2 dummies & 379,39 & 2,05 & 11,06 & 1984:1 & \\
\hline \multirow[t]{3}{*}{ Ireland } & & 2037,54 & 4,71 & & & \\
\hline & 1 dummy & 1691,57 & 4,31 & 15,62 & 1982:3 & 4,39 \\
\hline & 2 dummies & 1590,65 & 4,20 & 5,43 & 1987:2 & \\
\hline \multirow[t]{3}{*}{ Italy } & 0 dummy & 1252,27 & 3,69 & & & \\
\hline & 1 dummy & 974,37 & 3,27 & 20,42 & 1986:1 & 5,50 \\
\hline & 2 dummies & 884,10 & 3,13 & 8,43 & 1983:2 & \\
\hline \multirow[t]{3}{*}{ Netherlands } & 0 dummy & 408,80 & 2,11 & & & \\
\hline & 1 dummy & 322,48 & 1,88 & 19,42 & 1977:1 & 5,00 \\
\hline & 2 dummies & 310,02 & 1,86 & 3,52 & 1982:3 & \\
\hline \multirow[t]{3}{*}{ Portugal } & 0 dummy & 4724,43 & 7,17 & & & \\
\hline & 1 dummy & 4098,40 & 6,71 & 12,19 & 1985:2 & 4,01 \\
\hline & 2 dummies & 3733,42 & 6,44 & 8,10 & 1991:2 & \\
\hline \multirow[t]{3}{*}{ Spain } & 0 dummy & 1531,94 & 4,08 & & & \\
\hline & 1 dummy & 1226,98 & 3,67 & 18,31 & 1978:1 & 3,01 \\
\hline & 2 dummies & 1098,23 & 3,51 & 9,55 & $1976: 3$ & \\
\hline \multirow[t]{3}{*}{ UK } & 0 dummy & 1570,40 & 4,13 & & & \\
\hline & 1 dummy & 1267,62 & 3,73 & 17,74 & 1980:3 & 5,29 \\
\hline & 2 dummies & 1169,38 & 3,60 & 7,05 & 1990:4 & \\
\hline
\end{tabular}


Table 7 Inflation level regressions with structural breaks, 1974:1- 1998:2

\begin{tabular}{|l|c|c|c|c|c|c|c|c|c|c|}
\hline & Austria & Belgium & Denmark & France & Ireland & Italy & $\begin{array}{c}\text { Nether } \\
\text { lands }\end{array}$ & Portugal & Spain & UK \\
\hline Intercept & 1.54 & 0.70 & 9.99 & 4.36 & 9.84 & 9.14 & 0.23 & 18.40 & 6.63 & 9.38 \\
& $(3.25)$ & $(2.66)$ & $(6.90)$ & $(5.85)$ & $(2.70)$ & $(4.09)$ & $(0.80)$ & $(6.45)$ & $(3.12)$ & $(2.72)$ \\
\hline$\alpha_{0}$ & 0.56 & 0.85 & -0.06 & 0.59 & 0.41 & 0.41 & 0.93 & 0.07 & 0.81 & 0.41 \\
& $(5.42)$ & $(14.08)$ & $(-0.54)$ & $(8.57)$ & $(2.19)$ & $(3.20)$ & $(16.92)$ & $(0.49)$ & $(10.25)$ & $(2.95)$ \\
\hline$\alpha_{1}$ & 2.54 & 1.45 & 3.62 & 0.15 & -0.29 & 0.09 & 3.07 & 0.97 & -0.54 & -0.03 \\
& $(5.52)$ & $(1.18)$ & $(4.20)$ & $(0.28)$ & $(-0.46)$ & $(0.25)$ & $(3.39)$ & $(1.84)$ & $(-1.09)$ & $(-0.07)$ \\
\hline Dummy1 & - & - & -6.28 & -3.29 & -8.16 & -6.17 & - & -11.21 & -6.25 & -6.55 \\
& & & $(5.14)$ & $(-5.17)$ & $(-2.62)$ & $(-3.70)$ & & $(-5.35)$ & $(-2.79)$ & $(-2.15)$ \\
\hline adj. $\mathrm{R}^{\wedge} 2$ & 0.62 & 0.68 & 0.57 & 0.83 & 0.63 & 0.74 & 0.70 & 0.49 & 0.71 & 0.63 \\
\hline S.E.E. & 2.07 & 2.08 & 3.20 & 1.82 & 4.57 & 3.23 & 1.76 & 6.89 & 3.43 & 4.10 \\
\hline
\end{tabular}

Table 8 Inflation differential regressions with structural breaks, 1974:1- 1998:2

\begin{tabular}{|l|c|c|c|c|c|c|c|c|c|c|}
\hline & Austria & Belgium & Denmark & France & Ireland & Italy & $\begin{array}{c}\text { Nether } \\
\text { Lands }\end{array}$ & Portugal & Spain & UK \\
\hline Intercept & 2.30 & 5.11 & 4.39 & 3.97 & 9.38 & 7.22 & 3.55 & 11.49 & 6.35 & 6.54 \\
& $(2.91)$ & $(8.77)$ & $(5.89)$ & $(5.98)$ & $(6.22)$ & $(5.52)$ & $(6.44)$ & $(4.32)$ & $(3.46)$ & $(2.99)$ \\
\hline$\alpha_{0}$ & 0.01 & 0.21 & -0.01 & 0.27 & 0.21 & 0.25 & 0.26 & 0.25 & 0.75 & 0.32 \\
& $(0.04)$ & $(2.29)$ & $(-0.09)$ & $(2.91)$ & $(1.81)$ & $(2.18)$ & $(1.82)$ & $(1.75)$ & $(7.93)$ & $(2.92)$ \\
\hline$\alpha_{1}$ & 1.90 & 5.00 & 5.00 & -0.01 & -0.75 & 0.77 & 2.41 & 1.13 & -0.24 & 0.60 \\
& $(1.12)$ & $(3.34)$ & $(3.24)$ & $(-0.01)$ & $(1.37)$ & $(1.63)$ & $(1.25)$ & $(1.65)$ & $(-0.44)$ & $(1.27)$ \\
\hline Dummy1 & -1.81 & -3.45 & -4.85 & -4.12 & -8.52 & -5.37 & -3.55 & -7.46 & -5.92 & -4.81 \\
& $(-2.21)$ & $(-5.79)$ & $(-5.25)$ & $(-5.67)$ & $(-5.85)$ & $(-4.84)$ & $(-6.23)$ & $(-3.78)$ & $(-3.10)$ & $(-2.26)$ \\
\hline Dummy2 & - & -1.86 & - & - & - & - & - & - & - & - \\
& & $(-4.61)$ & & & & & & & & - \\
\hline adj. R^2 & 0.40 & 0.62 & 0.40 & 0.64 & 0.52 & 0.63 & 0.55 & 0.44 & 0.60 & 0.60 \\
\hline S.E.E. & 2.00 & 1.87 & 3.52 & 2.21 & 4.35 & 3.23 & 1.88 & 6.59 & 3.69 & 3.70 \\
\hline
\end{tabular}

